\title{
Assessing the Regional Imbalance between Environment and Economic Development within China
}

\author{
Xin $\mathrm{LI}^{1,2, a,{ }^{*}}$ and Yang GUAN ${ }^{1, b}$, \\ ${ }^{1}$ Strategic Planning Department, Chinese Academy for Environmental Planning, No.8 Dayangfang, \\ Beiyuan Road, Chaoyang District, Beijing, 100012, China \\ ${ }^{2}$ Institute of Recycling Economy, Beijing University of Technology, No.100, Pingleyuan, Chaoyang \\ District, Beijing, 100124, China \\ axinxinxn@163.com, b125840378@qq.com
}

Keywords: Coordination degree, Economy-environment system, Pressure for reform.

\begin{abstract}
This paper systematically analyzed the imbalance between economic development and ecological environmental protection in provinces of China. A coordination degree evaluation method based on comprehensive economic index and comprehensive environmental index has been established and used to assess the coordinated development at three levels. The results showed: 1) for all China's 31 provinces, the environmental conditions have been lagging behind the regional economic development. 2) The overall level of economic development and urbanization of most provinces were relatively high, average scores of indicators on GDP per capita, population urbanization, disposable income of urban residents were $0.6388,0.8207,0.9664$, respectively. 3) Pressures on deepening reform and expanding opening, and the gap between urban and rural development were main factors that led to the uncoordinated development of regional economy. 4) Most provinces made good performance in urban environmental management and air pollution control, but low investment in industrial pollution control and undesirable aquatic ecological environment were still major obstacles to coordinated development of economy-environment system.
\end{abstract}

\section{Introduction}

Contradiction between economic development and ecological environment has caused widespread concern throughout international and domestic communities, and formulating an effective response to such conflict has become a major concern in China which is in rapid modernization and urbanization process [1-7].

In the interests of promoting the sustainable development of China's economy and society, several scholars have conducted studies on the degree of coordination between economic development and ecological environment in both national [8-12] and provincial dimension [13-18]. Previous studies showed, in provinces and cities in eastern China with relative high level of economic and social development, degree of coordination between economic development and ecological environment have remained at a high level. Conversely, in provinces, autonomous regions and cities in central and western China, the degree of coordination has declined at a low level [19-25].

Recently, studies on degree of coordination between economy and environment have also extended to fields include energy, tourism and urbanization.

However, the methods and results of previous studies also showed a certain degree of onesidedness and inaccuracy. Current research has focused almost exclusively on macroeconomic indicators such as GDP and industrial structure, environmental pressure indicators such as industrial emission and ecological environmental status indicators such as landscape vegetation and land use patterns. The present study proposes a comprehensive index system for evaluating the degree of coordination between economic development and ecological environment in China. 


\section{Methodology}

\section{Index System for Coordination Degree Assessment}

The evaluation system is divided into three levels. The first layer, refers to as the target layer, includes economic development layer and ecological environment layer, measures the overall level of economic development and ecological environment status of coordination degree between economic development and ecological environment. The second layer, the criteria layer, includes 9 layers such as overall level of economic development, opening up, environmental pressure, etc. The third level includes 22 assessment indicators (Table 1).

Table 1 Risk assessment indicators with weight distribution and standardization

\begin{tabular}{|c|c|c|c|c|c|c|}
\hline Target Layer & Criteria Layer & Indicators & Unit & Direction & Weight & Expectations \\
\hline \multirow{13}{*}{$\begin{array}{l}\text { Economic } \\
\text { development } \\
\text { (T1) }\end{array}$} & \multirow{3}{*}{$\begin{array}{l}\text { Overall level of } \\
\text { economic } \\
\text { development } \\
\text { (C11) }\end{array}$} & GDP per capita (ED1) & CNY & + & 0.102 & 75000 \\
\hline & & Industrial added value per capita (ED2) & CNY & + & 0.078 & 25000 \\
\hline & & $\begin{array}{c}\text { Average annual growth rate of GDP in the past } \\
\text { five years (ED3) }\end{array}$ & $\%$ & + & 0.065 & 11 \\
\hline & \multirow{3}{*}{$\begin{array}{l}\text { Urbanization and } \\
\text { urban-rural } \\
\text { development } \\
\text { (C12) }\end{array}$} & \multirow{3}{*}{$\begin{array}{c}\text { Ratio of population urbanization (ED4) } \\
\text { Disposable income of urban residents (ED5) } \\
\text { Net income of farmers (ED6) }\end{array}$} & $\%$ & + & 0.081 & 65 \\
\hline & & & $\mathrm{CNY}$ & + & 0.056 & 25000 \\
\hline & & & $\mathrm{CNY}$ & + & 0.059 & 15000 \\
\hline & \multirow{4}{*}{$\begin{array}{l}\text { Opening up } \\
\text { (C13) } \\
\text { Industrial } \\
\text { structure (C14) }\end{array}$} & Foreign direct investment per capita (ED7) & Dollar & + & 0.111 & 2500 \\
\hline & & Total import and export (ED8) & 106 Dollar & + & 0.085 & 200000 \\
\hline & & Proportion of tertiary industry (ED9) & $\%$ & + & 0.129 & 60 \\
\hline & & $\begin{array}{l}\text { Ratio of real estate investment in total fixed } \\
\text { assets investment (ED10) }\end{array}$ & $\%$ & - & 0.071 & 15 \\
\hline & \multirow{3}{*}{$\begin{array}{l}\text { Pressure for } \\
\text { reform (C15) }\end{array}$} & $\begin{array}{c}\text { Asset-liability ratio of above-scale industrial } \\
\text { enterprises (ED11) }\end{array}$ & $\%$ & - & 0.064 & 45 \\
\hline & & $\begin{array}{l}\text { Output of industrial products of industries with } \\
\text { excess capacity (ED12) }\end{array}$ & See below & - & 0.039 & See below \\
\hline & & $\begin{array}{l}\text { Ratio of exports in total import and export } \\
\text { (ED13) }\end{array}$ & $\%$ & + & 0.060 & 60 \\
\hline \multirow{9}{*}{$\begin{array}{l}\text { Ecological } \\
\text { environment } \\
\text { (T2) }\end{array}$} & \multirow{3}{*}{$\begin{array}{l}\text { Environmental } \\
\text { pressure (C21) }\end{array}$} & $\begin{array}{c}\text { Industrial wastewater emission of } 104 \mathrm{CNY} \\
\text { industrial added value (EE1) }\end{array}$ & $\mathrm{t}$ & - & 0.112 & 10 \\
\hline & & $\begin{array}{c}\text { Industrial exhaust emission of } 104 \text { CNY } \\
\text { industrial added value (EE2) }\end{array}$ & $\mathrm{kg}$ & - & 0.122 & 100 \\
\hline & & CO2 emission of 104 CNY GDP (EE3) & $\mathrm{kg}$ & - & 0.142 & 1300 \\
\hline & $\begin{array}{l}\text { Sudden } \\
\text { environmental } \\
\text { risk (C22) }\end{array}$ & $\begin{array}{l}\text { Number of sudden environmental emergencies } \\
\text { (EE4) }\end{array}$ & Times/year & - & 0.125 & 2 \\
\hline & \multirow{2}{*}{$\begin{array}{l}\text { Environmental } \\
\text { governance } \\
\text { (C23) }\end{array}$} & Treatment rate of life garbage (EE5) & $\%$ & + & 0.110 & 100 \\
\hline & & $\begin{array}{l}\text { Ratio of industrial pollution control investment } \\
\text { in GDP (EE6) }\end{array}$ & $\%$ & + & 0.145 & 2 \\
\hline & \multirow{3}{*}{$\begin{array}{c}\text { Ecological } \\
\text { conditions (C24) }\end{array}$} & Water resources per capita (EE7) & $\mathrm{m}^{3}$ & + & 0.061 & 20000 \\
\hline & & Urban green coverage (EE8) & $\%$ & + & 0.093 & 60 \\
\hline & & Area ratio of nature reserve (EE9) & $\%$ & + & 0.091 & 18 \\
\hline
\end{tabular}

${ }^{a}$ CNY refers to China Yuan, which the official currency and the main currency in circulation of China.

\section{Data Set}

Taking 2014 as base year of evaluation, the values of economic development and ecological environment indicators in Table 1 are obtained in 31 provincial administrative regions (including provinces, municipalities and autonomous regions, except Hong Kong, Macao and Taiwan) from surveys, statistics, and yearbooks [26-28]. Meaning and calculation methods of part of indicators with Chinese characteristics are depicted below.

\section{Results}

\section{Oveall Results of Coordinated Development}

The computational results on comprehensive economic index, comprehensive environmental index and coordinated development index of provinces, municipalities and autonomous regions are shown in Table 2. It can be seen that, economic development scored higher than ecological environment in all the 31 provinces, municipalities and autonomous regions in China during the study period (year 2014). Moreover, there were large gaps between economic development and ecological environment. Indicated that in China, which is in rapid modernization and industrialization 
processes, the environmental pressure were synchronously upgrading with economic advancement and the ecological construction has been lagging behind economic development. For the degree of coordinated development, coordinated development indexes of 21 provinces, municipalities and autonomous regions including Beijing, Tianjin, Shanghai, Guangdong and Inner Mongolia exceeded 0.7000, and the average value of coordinated development indexes of which was 0.7224 . Indicated that the overall coordinated development level in China was low coordinated level and most provinces in China were in the early stage of coordinated development between economic development and ecological environment.

However, only Tianjin scored 0.8508 in coordinated development index and achieved the moderately coordinated level. Furthermore, coordinated development indexes of 10 provinces and autonomous regions including Shaanxi, Ningxia, Xinjiang, Henan and Shanxi were lower than 0.7000. Among which, Shanxi and Gansu scored 0.6361 and 0.6245, respectively. Indicated that the economy-environment systems of such 10 provinces and autonomous regions were in transition phase of coordinated development, Shanxi and Gansu were close to the edge of maladjustment.

Table 2 Oveall results ${ }^{\mathrm{a}}$

\begin{tabular}{cccccccc}
\hline Provinces & $\begin{array}{c}\text { Econo } \\
\text { my }\end{array}$ & $\begin{array}{c}\text { Environm } \\
\text { ent }\end{array}$ & $\begin{array}{c}\text { Coordi } \\
\text { nation }\end{array}$ & Provinces & $\begin{array}{c}\text { Econo } \\
\text { my }\end{array}$ & $\begin{array}{c}\text { Environm } \\
\text { ent }\end{array}$ & $\begin{array}{c}\text { Coordinati } \\
\text { on }\end{array}$ \\
\hline Beijing* & 0.8362 & 0.5431 & 0.7930 & Hubei & 0.6712 & 0.4629 & 0.7276 \\
Tianjin* & 0.8643 & 0.6460 & 0.8508 & Hunan & 0.6370 & 0.5700 & 0.7745 \\
Hebei & 0.6017 & 0.4511 & 0.7107 & Guangdong & 0.8344 & 0.5070 & 0.7702 \\
Shanxi & 0.5922 & 0.3431 & 0.6353 & Guangxi** & 0.5943 & 0.4265 & 0.6951 \\
Inner & 0.6939 & 0.5262 & 0.7663 & Hainan & 0.6429 & 0.4568 & 0.7203 \\
Mongolia** & & & & & \\
Liaoning & 0.7878 & 0.4642 & 0.7383 & Chongqing* & 0.7293 & 0.4627 & 0.7334 \\
Jilin & 0.6567 & 0.5127 & 0.7531 & Sichuan & 0.6145 & 0.5332 & 0.7537 \\
Heilongjiang & 0.6202 & 0.4606 & 0.7191 & Guizhou & 0.5254 & 0.3892 & 0.6613 \\
Shanghai* & 0.8729 & 0.4744 & 0.7489 & Yunnan & 0.5376 & 0.4327 & 0.6884 \\
Jiangsu & 0.8777 & 0.4667 & 0.7433 & Tibet** & 0.5579 & 0.5205 & 0.7334 \\
Zhejiang & 0.8607 & 0.4760 & 0.7498 & Shaanxi & 0.6485 & 0.3834 & 0.6709 \\
Anhui & 0.6018 & 0.4081 & 0.6845 & Gansu & 0.5536 & 0.3329 & 0.6245 \\
Fujian & 0.8312 & 0.4919 & 0.7598 & Qinghai & 0.6012 & 0.4487 & 0.7093 \\
Jiangxi & 0.6495 & 0.4688 & 0.7283 & Ningxia** & 0.6161 & 0.3822 & 0.6677 \\
Shandong & 0.7973 & 0.4575 & 0.7340 & Xinjiang** & 0.6088 & 0.3766 & 0.6629 \\
Henan & 0.6082 & 0.4107 & 0.6869 & & & & \\
\hline
\end{tabular}

a Provinces refer to the provincial administrative regions in China, including provinces, municipalities and autonomous regions. Provinces with $*$ and $* *$ refer to municipality and autonomous regions, respectively.

\section{Results of Main Economic Development Indicators}

\section{Overall Level of Economic Development and Industrial Structure.}

The computational results on indicators about overall level of economic development and industrial structure are shown in Table 3. It can be seen that, firstly, Beijing, Tianjin, Shanghai and Jiangsu scored 1 in ED1 (GDP per capita). Inner Mongolia and Zhejiang also achieved scores closed to 1. Liaoning, Fujian, Shandong and Guangdong scored more than 0.8000 in ED1, which was closed to the ideal status. Indicated that the circle of economy around the capital and Yangtze River Delta were still the most economically developed regions of China, and the eastern coastal region was still the key areas of China's economic development. However, except for Tianjin, central and western regions including Anhui, Hunan, Chongqing, Guizhou and Yunnan showed higher levels in ED7 (average annual growth rate of GDP). Indicated that such regions had great potential for development. 
In addition, it was apparent that for most provinces with high scores in ED2, (industrial added value per capita indicator) the scores of ED1 were also high. Indicated that provinces with high level of economic development also made good performance in industrial development. The results also showed that industries, especially manufacturing, is the backbone of China's economy. However, Shaanxi and Jilin scored 0.8470 and 0.9338 in ED2, respectively, the ED1 scores of these two provinces were only 0.6248 and 0.6688 . Imbalance between industry and regional economy in these two provinces implied that reliance on the energy industry, extensive development, single industrial structure and other problem demanded prompt solution.

Thirdly, ED1 score of Guangdong was only 0.8431. Such result was different from popular knowledge that Guangdong was the most economically developed province in China, and there was serious regional development imbalance in Guangdong, especially between Pearl River Delta and the rest areas.

Table 3 Results of overall level of economic development

\begin{tabular}{cccccccccc}
\hline Provinces & $\mathrm{ED}_{1}$ & $\mathrm{ED}_{2}$ & $\mathrm{ED}_{3}$ & $\mathrm{ED}_{7}$ & Provinces & $\mathrm{ED}_{1}$ & $\mathrm{ED}_{2}$ & $\mathrm{ED}_{3}$ & $\mathrm{ED}_{7}$ \\
\hline Beijing & 1 & 0.6964 & 1 & 0.7828 & Hubei & 0.6277 & 0.756 & 0.6909 & 1 \\
Tianjin & 1 & 1 & 0.8261 & 1 & Hunan & 0.5351 & 0.6383 & 0.7031 & 1 \\
Hebei & 0.5313 & 0.7221 & 0.6209 & 0.6913 & Guangdong & 0.8431 & 1 & 0.8166 & 0.7331 \\
Shanxi & 0.4664 & 0.5999 & 0.7416 & 0.6147 & Guangxi & 0.4396 & 0.5103 & 0.6311 & 0.9427 \\
Inner Mongolia & 0.9459 & 1 & 0.6586 & 0.7973 & Hainan & 0.5169 & 0.2279 & 0.8642 & 1 \\
Liaoning & 0.8693 & 1 & 0.6961 & 0.834 & Chongqing & 0.6358 & 0.6922 & 0.7797 & 1 \\
Jilin & 0.6688 & 0.9338 & 0.6028 & 0.8866 & Sichuan & 0.4674 & 0.5824 & 0.645 & 0.9704 \\
Heilongjiang & 0.5232 & 0.4992 & 0.7628 & 0.7019 & Guizhou & 0.3522 & 0.3581 & 0.7426 & 1 \\
Shanghai & 1 & 1 & 1 & 0.5949 & Yunnan & 0.3625 & 0.3308 & 0.7209 & 1 \\
Jiangsu & 1 & 1 & 0.7835 & 0.8598 & Tibet & 0.3861 & 0.0832 & 0.8911 & 1 \\
Zhejiang & 0.9725 & 1 & 0.7974 & 0.7001 & Shaanxi & 0.6248 & 0.847 & 0.6169 & 1 \\
Anhui & 0.457 & 0.6218 & 0.5899 & 1 & Gansu & 0.3518 & 0.3494 & 0.7337 & 0.9687 \\
Fujian & 0.8427 & 1 & 0.66 & 0.936 & Qinghai & 0.5268 & 0.6547 & 0.6173 & 1 \\
Jiangxi & 0.4613 & 0.6031 & 0.6133 & 0.9731 & Ningxia & 0.5543 & 0.5882 & 0.723 & 0.9317 \\
Shandong & 0.8094 & 1 & 0.7247 & 0.7904 & Xinjiang & 0.5381 & 0.5535 & 0.6804 & 1 \\
Henan & 0.4937 & 0.6702 & 0.6183 & 0.7849 & & & & & \\
\hline
\end{tabular}

\section{Urbanization and Urban-rural Development.}

The computational results on indicators about urbanization are shown in Table 4. It can be seen that, in Beijing, Tianjin and Shanghai, the degree of urbanization of the population and living standards of urban and rural residents achieved the desired state. Scores of the three indicators of Jiangsu, Zhejiang, Fujian and Guangdong also approach the ideal level. Indicated that, provinces in the eastern region, especially southeast coastal areas, had a high level of urbanization, urban and rural development of these provinces was also relatively balanced. Moreover, for all provinces except Xinjiang Qinghai, and Tibet, scores of ED5 (disposable income of urban residents) exceeded 0.9000, indicated that in most areas of China, income levels and living standards of urban residents were at or approach the ideal state. However, in central and western provinces, especially western provinces including Guizhou, Yunnan, Gansu, Qinghai and Tibet, the income level of farmers (ED6) was at a low level. Finally, for Shanxi, Inner Mongolia, Liaoning, Chongqing, Shaanxi, Gansu, Qinghai and Ningxia, there were large score gaps (over 0.2000) between ED4 (ratio of population urbanization) and ED6 (net income of farmers). Indicated that, in these provinces, the fast urbanization process has resulted in development disconnection between urban and rural. 
Table 4 Results of urbanization

\begin{tabular}{cccc|cccc}
\hline Provinces & ED4 & ED5 & ED6 & Provinces & ED4 & ED5 & ED6 \\
\hline Beijing & 1.0000 & 1.0000 & 1.0000 & Hubei & 0.8565 & 0.9941 & 0.7233 \\
Tianjin & 1.0000 & 1.0000 & 1.0000 & Hunan & 0.7582 & 1.0000 & 0.6707 \\
Hebei & 0.7588 & 0.9657 & 0.6791 & Guangdong & 1.0000 & 1.0000 & 0.8164 \\
Shanxi & 0.8274 & 0.9628 & 0.5873 & Guangxi & 0.7077 & 0.9868 & 0.5789 \\
Inner Mongolia & 0.9157 & 1.0000 & 0.6651 & Hainan & 0.8280 & 0.9795 & 0.6608 \\
Liaoning & 1.0000 & 1.0000 & 0.7461 & Chongqing & 0.9171 & 1.0000 & 0.6327 \\
Jilin & 0.8436 & 0.9287 & 0.7187 & Sichuan & 0.7123 & 0.9694 & 0.6232 \\
Heilongjiang & 0.8927 & 0.9044 & 0.6969 & Guizhou & 0.6157 & 0.9019 & 0.4447 \\
Shanghai & 1.0000 & 1.0000 & 1.0000 & Yunnan & 0.6420 & 0.9720 & 0.4971 \\
Jiangsu & 1.0000 & 1.0000 & 0.9972 & Tibet & 0.3967 & 0.8806 & 0.4906 \\
Zhejiang & 0.9980 & 1.0000 & 1.0000 & Shaanxi & 0.8090 & 0.9746 & 0.5288 \\
Anhui & 0.7562 & 0.9935 & 0.6611 & Gansu & 0.6413 & 0.8722 & 0.4184 \\
Fujian & 0.9507 & 1.0000 & 0.8433 & Qinghai & 0.7653 & 0.8923 & 0.4855 \\
Jiangxi & 0.7726 & 0.9724 & 0.6744 & Ningxia & 0.8250 & 0.9314 & 0.5607 \\
Shandong & 0.8463 & 1.0000 & 0.7922 & Xinjiang & 0.7090 & 0.9286 & 0.5816 \\
Henan & 0.6954 & 0.9469 & 0.6644 & & & & \\
\hline
\end{tabular}

\section{Pressure for Reforms and Opening Up.}

According to related government documents and planning, supply-side reform is one of the core tasks of China's development in the thirteenth Five-Year period. To characterize the difficulty of supply-side reform, the scoring evaluation results of indicators about pressure for reforms and opening up are shown in Table 5. The results showed, firstly, coastal provinces and municipalities including Beijing, Tianjin, Shanghai, Zhejiang, Jiangsu, Fujian, Shandong, Liaoning and Guangdong scored high in ED7 (foreign direct investment per capita) and ED8 (total import and export). Coastal regions showed high degrees of opening up and strong ability to attract foreign investment. However, such provinces and municipalities scored uneven in ED13 (ratio of exports in total import and export), indicated that due to the varied industrial structure and market demand, the provinces had different emphases on import and export. From Table 7, in energy provinces including Hebei, Shanxi, Liaoning and Xinjiang, and manufacturing provinces including Jiangsu, Zhejiang and Guangdong, the ratio of exports was high. Indicated that heavy industries and manufacturing were dominated sectors of China's foreign economy and trade. In addition, it is noteworthy that for Tianjin, Shanxi, Inner Mongolia, Liaoning, Jilin, Jiangxi, Hainan and Chongqing there were large score gaps (over 0.2500) between ED7 and ED8. Showed that such provinces had great potential for opening up.

Secondly, inventory backlog of real estate is the primary problem China faced in destocking reform. From the scoring results of ED10 (ratio of real estate investment in total fixed assets investment), scores of Beijing and Shanghai were 0.2796 and 0.2815 , respectively. Showed that the two cities with highest level of economic and social development in China were under the greatest pressure of real estate destocking. Meanwhile, Zhejiang, Guangdong, Hainan and Chongqing have also been facing grim situation of real estate destocking.

Thirdly, high debt is the major obstacle in the processes of industrial structure adjustment and upgrading of China's enterprises. From the scoring results of ED11 (asset-liability ratio of abovescale industrial enterprises), all of the 31 provinces, municipalities and autonomous regions made poor performance in this indicator. In energy and industrial province such as Hebei, Shanxi, Inner Mongolia, Xinjiang and provinces with relatively backward economic development such as Qinghai, Gansu, the situation of high debt enterprises was particularly serious.

Finally, overcapacity is also a major problem of industrial structure optimization and reform of economic mode in China. From the scoring results of ED12 (output of industrial products of industries with excess capacity), Hebei, Liaoning, Jiangsu, Shandong, Henan, Hubei, and Guangdong were in serious condition of overcapacity. Meanwhile, severity of overcapacity didn’t 
show any correlation with economic development level. Indicated that industrial and product structure, and the reliance of regional economy on leading industries were devisive factors of decapacity reform.

Table 5 Results of pressure for reforms and opening up

\begin{tabular}{ccccccc}
\hline Provinces & $\mathrm{ED}_{7}$ & $\mathrm{ED}_{8}$ & $\mathrm{ED}_{10}$ & $\mathrm{ED}_{11}$ & $\mathrm{ED}_{12}$ & $\mathrm{ED}_{13}$ \\
\hline Beijing & 1 & 1 & 0.2796 & 0.5615 & 1 & 0.2308 \\
Tianjin & 1 & 0.6694 & 0.9283 & 0.4696 & 0.4247 & 0.6043 \\
Hebei & 0.2805 & 0.2994 & 0.9855 & 0.3935 & 0.0841 & 0.9175 \\
Shanxi & 0.3574 & 0.0812 & 1 & 0.3561 & 0.3841 & 0.8474 \\
Inner & 0.3519 & 0.0728 & 1 & 0.4047 & 0.7807 & 0.6757 \\
Mongolia & 1 & 0.5700 & 0.6998 & 0.4620 & 0.2530 & 0.7928 \\
Liaoning & 0.4037 & 0.1319 & 1 & 0.4875 & 1 & 0.3369 \\
Jilin & 0.2086 & 0.1945 & 1 & 0.4488 & 1 & 0.6856 \\
Heilongjiang & 1 & 1 & 0.2815 & 0.5965 & 0.8731 & 0.6931 \\
Shanghai & 1 & 1 & 0.7634 & 0.5054 & 0.1638 & 0.9332 \\
Jiangsu & 1 & 1 & 0.5011 & 0.5053 & 0.4028 & 1 \\
Zhejiang & 0.2632 & 0.2459 & 0.7562 & 0.4891 & 0.3851 & 0.9850 \\
Anhui & 1 & 0.8870 & 0.5970 & 0.5608 & 0.3816 & 0.9838 \\
Fujian & 0.4919 & 0.2137 & 1 & 0.5017 & 0.5077 & 1 \\
Jiangxi & 1 & 1 & 0.5037 & 0.2265 & 0.8039 \\
Shandong & 0.6784 & 0.3249 & 1 & 0.5738 & 0.2885 & 0.9325 \\
Henan & 0.2080 & 0.325 & 0.9523 \\
Hubei & 0.4452 & 0.2152 & 0.8628 & 0.4872 & 0.2178 & 0.9951 \\
Hunan & 0.2291 & 0.1542 & 1 & 0.5323 & 0.4103 & 0.9233 \\
Guangdong & 1 & 1 & 0.5163 & 0.5462 & 0.2440 & 0.9230 \\
Guangxi & 0.2622 & 0.2027 & 1 & 0.4504 & 0.4650 & 0.4284 \\
Hainan & 1 & 0.0793 & 0.3261 & 0.4597 & 1 & 1 \\
Chongqing & 0.7524 & 0.4772 & 0.5076 & 0.4393 & 0.7460 & 0.9826 \\
Sichuan & 0.3389 & 0.3510 & 0.7986 & 0.4598 & 0.3411 & 1 \\
Guizhou & 0.1470 & 0.0539 & 0.6189 & 0.4442 & 0.5209 & 1 \\
Yunnan & 0.1786 & 0.1480 & 0.6059 & 0.4129 & 0.5175 & 0.9762 \\
Tibet & 0.1392 & 0.0113 & 1 & 0.5390 & 1 & 1 \\
Shaanxi & 0.3950 & 0.1368 & 1 & 0.4322 & 0.5459 & 0.7831 \\
Gansu & 0.0870 & 0.0432 & 1 & 0.4151 & 1 & 0.9489 \\
Qinghai & 0.1770 & 0.0086 & 1 & 0.3191 & 1 & 1 \\
Ningxia & 0.2600 & 0.0272 & 0.7270 & 0.4029 & 0.9839 & 1 \\
Xinjiang & 0.1100 & 0.1384 & 1 & 0.3196 & & \\
\hline & & & & & 1 & \\
\hline
\end{tabular}

\section{Results of Main Ecological Environmental Indicators}

\section{Environmental Pressure and Sudden Environmental Risk.}

Scoring results of indicators about environmental pressure and sudden environmental risk are shown in Table 6. The two indicators characterize sudden and cumulative risks that regional ecological environments suffered. Firstly, for all the 31 provinces, municipalities and autonomous regions except Tianjin and Inner Mongolia, scores of EE1 (industrial wastewater emission of 104 CNY industrial added value) were low. Indicated that, high discharge intensity of industrial wastewater was a common environmental stress factor in China.

Secondly, it can be found from the scoring results of EE2 (industrial exhaust emission of 104 CNY industrial added value), discharge pressure of industrial exhaust showed significant heterogeneities on location, regional leading industries and energy structure. Energy and heavy industry provinces such as Hebei, Shanxi, Inner Mongolia, Heilongjiang and Xinjiang, generally showed strong industrial emission intensity. Indicated that the economic-environmental efficiency of such provinces was relative low. Economically developed regions including Beijing, Tianjin, 
Shanghai, Jiangsu, Zhejiang and Fujian scored relative high in indicator EE2. It is noteworthy that, there was a great gap between scores of EE1 and EE2 in provinces along large rivers. For instance, emission intensity of industrial wastewater (characterized by EE1) was higher than industrial exhaust (characterized by EE2) in Shanghai, Jiangsu, Zhejiang that close to Yangtze River, Guangdong that close to Pearl River and Fujian with abundant water resources. Indicated that, due to the great demand for water consumption, industrial enterprises that may emit large quantities of industrial wastewater were mostly located in the surrounding large water bodies.

Thirdly, EE3 (CO2 emission of 104 CNY GDP) scores of provinces in central China including Hebei, Shanxi, Inner Mongolia and northwestern China including Gansu, Qinghai, Ningxia, Xinjiang were low. Indicated that, carbon emission intensity of central and western provinces was relative high and the energy efficiency of such provinces was relative low. Shanxi, Inner Mongolia and Ningxia scored $0.1657,0.2212$ and 0.1385 in EE3, respectively, indicated that the energy structure and efficiency of these three provinces needed to be improved.

Table 6 Results of environmental pressure and sudden environmental risk

\begin{tabular}{|c|c|c|c|c|c|c|c|c|c|}
\hline Provinces & $\mathrm{EE}_{1}$ & $\mathrm{EE}_{2}$ & $\mathrm{EE}_{3}$ & $\mathrm{EE}_{4}$ & Provinces & $\mathrm{EE}_{1}$ & $\mathrm{EE}_{2}$ & $\mathrm{EE}_{3}$ & $\mathrm{EE}_{4}$ \\
\hline Beijing & $\begin{array}{c}0.248 \\
6\end{array}$ & 1 & 1 & $\begin{array}{c}0.181 \\
8\end{array}$ & Hubei & $\begin{array}{c}0.364 \\
4\end{array}$ & 0.659 & 0.666 & 0.4 \\
\hline Tianjin & $\begin{array}{c}0.792 \\
2\end{array}$ & 1 & 0.703 & 1 & Hunan & $\begin{array}{c}0.346 \\
8\end{array}$ & $\begin{array}{c}0.642 \\
7\end{array}$ & $\begin{array}{c}0.811 \\
9\end{array}$ & 1 \\
\hline Hebei & $\begin{array}{c}0.430 \\
3\end{array}$ & $\begin{array}{c}0.296 \\
2\end{array}$ & $\begin{array}{c}0.288 \\
4\end{array}$ & 1 & $\begin{array}{c}\text { Guangdon } \\
\text { g }\end{array}$ & 0.322 & 1 & $\begin{array}{c}0.943 \\
2\end{array}$ & 0.087 \\
\hline Shanxi & $\begin{array}{c}0.377 \\
2\end{array}$ & $\begin{array}{c}0.144 \\
5\end{array}$ & $\begin{array}{c}0.165 \\
7\end{array}$ & $\begin{array}{c}0.333 \\
3\end{array}$ & Guangxi & $\begin{array}{c}0.276 \\
6\end{array}$ & $\begin{array}{c}0.462 \\
3\end{array}$ & $\begin{array}{c}0.640 \\
1\end{array}$ & 0.25 \\
\hline $\begin{array}{c}\text { Inner } \\
\text { Mongolia }\end{array}$ & $\begin{array}{c}0.706 \\
3\end{array}$ & 0.22 & $\begin{array}{c}0.221 \\
2\end{array}$ & 1 & Hainan & $\begin{array}{c}0.130 \\
7\end{array}$ & $\begin{array}{c}0.341 \\
3\end{array}$ & $\begin{array}{c}0.589 \\
4\end{array}$ & $\begin{array}{c}0.666 \\
7\end{array}$ \\
\hline Liaoning & $\begin{array}{c}0.481 \\
5\end{array}$ & $\begin{array}{c}0.419 \\
5\end{array}$ & $\begin{array}{c}0.390 \\
1\end{array}$ & 0.5 & Chongqing & $\begin{array}{c}0.354 \\
9\end{array}$ & $\begin{array}{c}0.467 \\
1\end{array}$ & 0.826 & 0.125 \\
\hline Jilin & $\begin{array}{c}0.525 \\
9\end{array}$ & 0.46 & 0.506 & 1 & Sichuan & $\begin{array}{c}0.357 \\
8\end{array}$ & $\begin{array}{c}0.654 \\
6\end{array}$ & $\begin{array}{c}0.761 \\
6\end{array}$ & $\begin{array}{c}0.285 \\
7\end{array}$ \\
\hline $\begin{array}{l}\text { Heilongjian } \\
\text { g }\end{array}$ & $\begin{array}{c}0.319 \\
7\end{array}$ & $\begin{array}{c}0.239 \\
6\end{array}$ & $\begin{array}{c}0.410 \\
9\end{array}$ & 1 & Guizhou & $\begin{array}{c}0.283 \\
2\end{array}$ & 0.175 & $\begin{array}{c}0.334 \\
3\end{array}$ & $\begin{array}{c}0.666 \\
7\end{array}$ \\
\hline Shanghai & $\begin{array}{c}0.332 \\
9\end{array}$ & 1 & 0.784 & $\begin{array}{c}0.018 \\
5\end{array}$ & Yunnan & $\begin{array}{c}0.247 \\
5\end{array}$ & $\begin{array}{c}0.259 \\
5\end{array}$ & $\begin{array}{c}0.468 \\
4\end{array}$ & $\begin{array}{c}0.666 \\
7\end{array}$ \\
\hline Jiangsu & $\begin{array}{c}0.448 \\
5\end{array}$ & $\begin{array}{c}0.929 \\
4\end{array}$ & $\begin{array}{c}0.699 \\
6\end{array}$ & $\begin{array}{c}0.028 \\
6\end{array}$ & Tibet & $\begin{array}{c}0.121 \\
4\end{array}$ & $\begin{array}{c}0.099 \\
5\end{array}$ & 1 & 1 \\
\hline Zhejiang & 0.401 & 1 & $\begin{array}{c}0.708 \\
2\end{array}$ & $\begin{array}{c}0.074 \\
1\end{array}$ & Shaanxi & $\begin{array}{c}0.548 \\
3\end{array}$ & 0.364 & $\begin{array}{c}0.430 \\
5\end{array}$ & $\begin{array}{c}0.024 \\
4\end{array}$ \\
\hline Anhui & $\begin{array}{c}0.347 \\
2\end{array}$ & $\begin{array}{c}0.484 \\
1\end{array}$ & $\begin{array}{c}0.563 \\
9\end{array}$ & $\begin{array}{c}0.222 \\
2\end{array}$ & Gansu & 0.343 & $\begin{array}{c}0.168 \\
9\end{array}$ & $\begin{array}{c}0.294 \\
7\end{array}$ & $\begin{array}{c}0.090 \\
9\end{array}$ \\
\hline Fujian & $\begin{array}{c}0.400 \\
1\end{array}$ & $\begin{array}{c}0.918 \\
2\end{array}$ & $\begin{array}{c}0.779 \\
8\end{array}$ & 0.1 & Qinghai & $\begin{array}{c}0.414 \\
9\end{array}$ & $\begin{array}{c}0.180 \\
5\end{array}$ & $\begin{array}{c}0.271 \\
6\end{array}$ & $\begin{array}{c}0.333 \\
3\end{array}$ \\
\hline Jiangxi & $\begin{array}{c}0.328 \\
8\end{array}$ & $\begin{array}{c}0.445 \\
6\end{array}$ & $\begin{array}{c}0.775 \\
6\end{array}$ & $\begin{array}{c}0.333 \\
3\end{array}$ & Ningxia & $\begin{array}{c}0.261 \\
2\end{array}$ & $\begin{array}{c}0.095 \\
4\end{array}$ & $\begin{array}{c}0.138 \\
5\end{array}$ & $\begin{array}{c}0.285 \\
7\end{array}$ \\
\hline Shandong & $\begin{array}{c}0.492 \\
6\end{array}$ & 0.577 & 0.509 & $\begin{array}{c}0.333 \\
3\end{array}$ & Xinjiang & $\begin{array}{c}0.309 \\
5\end{array}$ & $\begin{array}{c}0.125 \\
7\end{array}$ & 0.253 & 0.4 \\
\hline Henan & $\begin{array}{c}0.373 \\
9 \\
\end{array}$ & $\begin{array}{c}0.451 \\
4 \\
\end{array}$ & 0.537 & $\begin{array}{c}0.333 \\
3 \\
\end{array}$ & & & & & \\
\hline
\end{tabular}

\section{Environmental Governance and Ecological Conditions.}

Scoring results of indicators about environmental governance and ecological conditions are shown in Table 7. From the scoring results of EE5 (treatment rate of life garbage) and EE8 (urban green coverage), most of provinces made good performances in urban greening, treatment and disposal of municipal solid waste. Indicated that most provinces and cities achieved some success in the field of 
urban environmental management. However, scoring results of EE6 (Ratio of industrial pollution control investment in GDP) showed the investment intensity in industrial pollution control of all the 31 provinces was low and far below the ideal level.

Moreover, scoring results of EE7 (water resources per capita) showed that, water scarcity was a major ecological environmental problem China faced. Although in areas with abundant water resources such as Jiangxi, Fujian and Guangxi, water resources per capita were below the ideal level.

From the scoring results of EE9 (area ratio of nature reserve), nature reserve area showed certain spatial heterogeneities. Nature reserve area of the middle and lower reaches of the Yellow River Basin (including Hebei, Shandong, Shanxi, Henan and Shaanxi), middle and lower reaches of Yangtze River Basin (including Shanghai, Jiangsu, Zhejiang, Anhui, Hunan and Hubei) and southeast coast (including Fujian, Guangdong and Guangxi) were relative small.

Table 7 Results of environmental governance and ecological conditions ${ }^{\mathrm{a}}$

\begin{tabular}{cccccccccccc}
\hline Provinces & $\mathrm{EE}_{5}$ & $\mathrm{EE}_{6}$ & $\mathrm{EE}_{7}$ & $\mathrm{EE}_{8}$ & $\mathrm{EE}_{9}$ & Provinces & $\mathrm{EE}_{5}$ & $\mathrm{EE}_{6}$ & $\mathrm{EE}_{7}$ & $\mathrm{EE}_{8}$ & $\mathrm{EE}_{9}$ \\
\hline Beijing & 1.00 & 0.02 & 0.00 & 0.82 & 0.44 & Hubei & 0.90 & 0.05 & 0.08 & 0.63 & 0.31 \\
Tianjin & 0.97 & 0.07 & 0.00 & 0.58 & 0.44 & Hunan & 1.00 & 0.03 & 0.13 & 0.64 & 0.34 \\
Hebei & 0.87 & 0.15 & 0.01 & 0.70 & 0.21 & Guangdong & 0.86 & 0.03 & 0.08 & 0.69 & 0.40 \\
Shanxi & 0.92 & 0.12 & 0.02 & 0.67 & 0.39 & Guangxi & 0.95 & 0.06 & 0.21 & 0.66 & 0.33 \\
Inner Mongolia & 0.96 & 0.22 & 0.11 & 0.66 & 0.64 & Hainan & 1.00 & 0.08 & 0.21 & 0.69 & 0.39 \\
Liaoning & 0.92 & 0.07 & 0.02 & 0.67 & 0.74 & Chongqing & 0.99 & 0.02 & 0.11 & 0.68 & 0.57 \\
Jilin & 0.62 & 0.06 & 0.06 & 0.60 & 0.72 & Sichuan & 0.95 & 0.04 & 0.16 & 0.63 & 1.00 \\
Heilongjiang & 0.59 & 0.06 & 0.12 & 0.60 & 0.83 & Guizhou & 0.93 & 0.10 & 0.17 & 0.57 & 0.28 \\
Shanghai & 1.00 & 0.04 & 0.01 & 0.64 & 0.29 & Yunnan & 0.93 & 0.10 & 0.18 & 0.64 & 0.42 \\
Jiangsu & 0.98 & 0.04 & 0.03 & 0.71 & 0.22 & Tibet & - & 0.06 & 1.00 & 0.73 & 1.00 \\
Zhejiang & 1.00 & 0.08 & 0.10 & 0.68 & 0.09 & Shaanxi & 0.96 & 0.09 & 0.05 & 0.68 & 0.32 \\
Anhui & 1.00 & 0.04 & 0.06 & 0.69 & 0.21 & Gansu & 0.63 & 0.13 & 0.04 & 0.51 & 0.91 \\
Fujian & 0.98 & 0.09 & 0.16 & 0.71 & 0.17 & Qinghai & 0.86 & 0.16 & 0.68 & 0.53 & 1.00 \\
Jiangxi & 0.93 & 0.04 & 0.18 & 0.74 & 0.42 & Ningxia & 0.93 & 0.50 & 0.01 & 0.63 & 0.57 \\
Shandong & 1.00 & 0.12 & 0.01 & 0.71 & 0.27 & Xinjiang & 0.82 & 0.17 & 0.16 & 0.61 & 0.65 \\
Henan & 0.93 & 0.08 & 0.02 & 0.64 & 0.24 & & & & & & \\
\hline
\end{tabular}

\section{Discussion and Conclusion}

Comprehensive economic evaluation index and comprehensive environmental evaluation index are calculated and evaluated to characterize the level of economic development and ecological environmental conditions in 31 provinces, municipalities and autonomous regions of China. For all the 31 provincial-level administrative regions, the ecological and environmental conditions have been lagging behind the regional economic development. Moreover, except a small part of central and western provinces such as Hunan, Sichuan and Tibet, there were relative big gaps between ecological environmental construction and economic development in most provinces. Based on calculation and evaluation results of economic and environmental indexes, coordinated development index is defined to characterize the degree of coordination between economic development and ecological environment. The average value of coordinated development indexes of 31 provinces was 0.7224 and coordinated development indexes of 21 provinces were higher than 0.7000. Indicated that the overall coordinated development level in China was low coordinated level and most provinces in China were in the early stage of coordinated development. Coordination degrees of eastern regions were higher than central and western regions, implied the regional and spatial imbalance of coordinated development.

From the indicators on economic development, the overall level of economic development and urbanization of most provinces were relative high. However, in parts of central and western provinces, over-reliance on industry and imbalance between urban and rural development were major obstacles to coordinated development. Reforms, especially supply-side reform and expanding 
of opening up, are major tasks in the process of economic and social development during Thirteen Five period. From the computation results of relative indicators, high debt and overcapacity were the main resistance to the reform process and coordinated development. From the indicators on ecological environment, most provinces made good performance in urban environmental management and air pollution control. However, low investment in industrial pollution control and undesirable aquatic ecological environment may affect the coordinated development of economyenvironment system.

At the regional level, regional development imbalance has been a common feature of the two regions. Therefore, it's necessary to develop integrated development policy and adjust the mode of development and prevent the development disconnection between Beijing and surrounding areas, Yangtze River Delta and middle and upper reaches of Yangtze River basin.

\section{References}

[1] Shafik N, Bandyo PadhyayS, Economic Growth and Environmental Quality: Time Series and Cross-country Evidence. In: Background Paper for world Development Report 1992, World Bank, Washington DC, 1992, pp 34-46.

[2] Bojö J, Mäler K G, Unemo L, Environment and development: an economic approach. In: Springer Science \& Business Media, Berlin, 2013.

[3] Krugman P, First nature, second nature and metropolitan location. Journal of Regional Science 33 (1993) 129-44.

[4] Grossman G.M.; .Kreuger A.B, Economic growth and the environment. The Quarterly Journal of Economics 112 (1995) 353-67.

[5] Kosaka Y, Xie SP, Recent global-warming hiatus tied to equatorial. Pacific surface cooling Nature 501 (2013) 403-7.

[6] Sun D, Zhang J, Zhu C, Hu Y, Zhou L,An Assessment of China's Ecological Environment Quality Change and Its Spatial Variation. Acta Geographica Sinica 67(12), 2013, 1599-610 (in Chinese).

[7] Zhang $\mathrm{XH}, \mathrm{Hu} \mathrm{H}$, Zhang $\mathrm{R}$, Interactions between China' s economy, energy and the air emissions and their policy implications. Renewable Sustainable Energy Rev 38, 2014, 624-38.

[8] Zhang X, Chi T, Differentiating and analysis of the coordination degree between economic development and environment of provinces (regions) in China. Geographica Research 20(4) (2001) 506-15 (in Chinese).

[9] Wei X, Zhao J, Wei W, Jie B, Coordinated development of ecological-economic system and spatial evolution based on county unit in China. Progress in Geography 33(11) (2014) 1535-45 (in Chinese).

[10] Rohde RA, Muller RA, Air pollution in China: mapping of concentrations and sources. Plos one 10(8) (2015) 1-14.

[11] Li T, Han Y, Li Y, Urgency, development stage and coordination degree analysis to support differentiation management of water pollution emission control and economic development in the eastern coastal area of China. Ecol. Indic.71 (2016) 406-15.

[12] Honti M, Schuwirth N, Rieckermann J, Can integrative catchment management mitigate future water quality issues caused by climate change and socio-economic development? Hydrol. Earth Syst. Sci. 21(3) (2017) 1-28.

[13] Gendron C, beyond environmental and ecological economics: Proposal for an economic sociology of the environment. Ecol. Econ. 105 (2014) 240-53. 
[14] Ma L, Jin F, Liu Y, Spatial Pattern and Industrial Sector Structure Analysis on the Coupling and Coordinating Degree of Regional Economic Development and Environmental Pollution in China. Acta Geographica Sinica 67(10) (2012) 1299-307.

[15] Song M, Xu L, Wang S, Zhang L, Coordinated development of economy and environment in Anhui Province based on small sample data. Geographica Research, 32(8) (2013) 1402-10 (in Chinese).

[16] Bian Y, Yan S, Xu H, Efficiency evaluation for regional urban water use and wastewater decontamination systems in China: A DEA approach. Resour. Conserv. Recycl. 83 (2014) 15-23.

[17] Tang X, Qiu F, Zhu C, Zhang C, Yao X, Temporal-spatial Change of Coordinated Development between Economy and Environment in Jiangsu Province. World Regional Studies 24(2) (2015) 68-77 (in Chinese).

[18] Eisemann J, Heginbotham E, Mitchell D, China and the developing world: Beijing's strategy for the twenty-first century. China Quarterly 192 (2007) 1023-4

[19] Su J, Hu Z, Tang L, The Geographic Distribution Characters and Dynamic Evolution for the Coordination Degree of Energy-Economic-Environmental (3E) in China. Economic Geography 33(9) (2013) 19-24 (in Chinese).

[20] Brajer V, Mead RW, Xiao F, Health benefits of tunneling through the Chinese environmental Kuznets curve. Ecol. Econ. 66(4) (2008) 674-86.

[21] Costantini V, Monni S, Environment, human development and economic growth. Ecol. Econ. 64(4) (2008) 867-80.

[22] Diao XD, Zeng SX, Tam CM, EKC analysis for studying economic growth and environmental quality: a case study in China. J. Cleaner Prod.17(5) (2009) 541-48.

[23] Wang K, Li Y, Jiang, H, Research on Coupling Coordinative Gegree of Tourism-EconomyEnvironment_A Case Study of Liaoning Coastal Economic Belt. Resource Development \& Market 29(6) (2013) 658-61. (in Chinese).

[24] Aşıcı AA, Economic growth and its impact on environment: A panel data analysis. Ecol. Indic. 24(1) (2003) 324-33.

[25] Pandey B, Agrawal M, Singh S, and Assessment of air pollution around coal mining area: emphasizing on spatial distributions, seasonal variations and heavy metals, using cluster and principal component analysis. Atmos. Pollut. Res. 5(1) (2014) 79-86.

[26] China's National Bureau of Statistics, China Statistical Yearbook 2015. China Statistics Press, Beijing, 2015 (in Chinese).

[27] Grooten M, Living planet report 2012. Biodiversity, biocapacity and better choices. Global Footprint Network, ZSL Living Conservation Gland: WWF International: WWF, 160, 2012.

[28] National Bureau of Statistics of China, National Development and Reform Commissio. China Energy Statistical Yearbook. China Statistics Press, Beijing, 2014. (in Chinese). 